\title{
Analisis Pengaruh Fasilitas Kesehatan terhadap Kematian Bayi di Jawa Timur Menggunakan Pendekatan Geographically Weighted Regression
}

\author{
An Analysis of the Effects of Health Facility on Infant Mortality in East Java \\ Using a Geographically Weighted Regression Approach
}

\author{
Harun Al Azies ${ }^{1}$ \\ 1) Statistika, Fakultas Matematika dan Ilmu Pengetahuan Alam, Universitas PGRI Adi Buana Surabaya, Jalan Dukuh \\ Menanggal XII Surabaya 60234 Jawa Timur, Indonesia \\ Korespondensi: harunalazies@gmail.com
}

Submitted: 11 Juli 2019, Revised: 28 Agustus 2019, Accepted: 30 Agustus 2019

https://doi.org/10.22435/jpppk.v3i2.2431

\begin{abstract}
Abstrak
Jawa Timur merupakan salah satu provinsi dengan tingkat kematian bayi yang tinggi. Analisis pengaruh fasilitas kesehatan terhadap kejadian kematian bayi di Jawa Timur dapat membantu merumuskan kebijakan dan program kesehatan ibu dan anak. Tujuan analisis ini adalah untuk mengetahui hubungan antara ketersediaan posyandu, klinik Keluarga Berencana (KB), Pos Pelayanan Keluarga Berencana Desa (PPKBD), rumah sakit bersalin, puskesmas pembantu, dan apotek dengan kejadian kematian bayi. Terdapat kemungkinan bahwa wilayah sekitar daerah dengan kematian bayi yang tinggi akan memiliki beban kematian bayi yang tinggi pula. Oleh karena itu diperlukan suatu metode pemodelan statistik dengan memperhitungkan aspek lokasi yaitu metode Geographically Weighted Regression (GWR). Analisis dan pembahasan menggunakan metode GWR mendapatkan bahwa faktor ketersediaan Posyandu Strata Pratama dan Madya serta Puskesmas Pembantu memengaruhi kejadian kematian bayi di wilayah Pacitan, Ponorogo, Pasuruan, Kediri (kota), Malang (kota), Pasuruan (kota), Banyuwangi, dan Probolinggo. Sementara itu, di wilayah Kabupaten Bondowoso, Bangkalan, Batu (Kota), Blitar, Sidoarjo, dan Sumenep kejadian kematian bayi dipengaruhi oleh faktor ketersediaan Posyandu Strata Pratama dan Madya. Faktor ketersediaan Posyandu Strata Purnama dan Mandiri memengaruhi kejadian kematian bayi di wilayah Lamongan, Madiun (Kota), Kediri, dan Malang sedangkan di wilayah Kabupaten Lumajang, Jombang, Magetan, Bojonegoro, dan Jember dipengaruhi oleh ketersediaan Posyandu Strata Purnama, dan Kabupaten Gresik oleh ketersediaan Posyandu Strata Pratama. Ketersediaan fasilitas kesehatan penunjang yang terjamin, adanya kesadaran ibu untuk menjaga kesehatan diri dan asupan nutrisi untuk bayi, serta rutin mengecek kesehatan merupakan upaya untuk menekan tingkat kematian bayi di Jawa Timur.
\end{abstract}

Kata kunci: fasilitas kesehatan, Geographically Weighted Regression, kematian bayi, spasial analisis

\begin{abstract}
East Java is one of the provinces with high infant mortality rates. Analysis of the influence of health facilities on infant mortality in East Java can help to formulate maternal and child health policies and programs. The purpose of this analysis is to determine the relationship between the availability of Integrated Healthcare Center (Posyandu), family planning clinics, village family planning services (PPKBD), maternity hospitals, supporting health centers, and pharmacies with the incidence of infant mortality. There is a possibility that the surrounding area of an area with high infant mortality will have the same burden. Therefore we need a statistical modeling method that takes into account the location aspects, such as the Geographically Weighted Regression (GWR) method. Analysis and discussion using GWR analysis showed that the availability of Posyandu Strata Pratama and Madya, as well as the supporting health centers, affected infant mortality incidence in Pacitan, Ponorogo, Pasuruan, Kediri (city), Malang (city), Pasuruan (city), Banyuwangi, and Probolinggo. While in Bondowoso
\end{abstract}


Regency, Bangkalan, Batu (city), Blitar, Sidoarjo, and Sumenep, it was affected by the availability of Posyandu Strata Pratama and Madya. The availability of Posyandu Strata Purnama and Mandiri affected the incidence of infant mortality in Lamongan, Madiun (City), Kediri, and Malang areas. The availability of Posyandu Strata Purnama influenced the incidence of infant mortality in Lumajang, Jombang, Magetan, Bojonegoro, and Jember districts while Gresik Regency is affected by the availability of Posyandu Strata Pratama. The availability of supporting health facilities, the awareness of mothers to maintain personal health and nutritional intake for infants, and routine health check-up are efforts to reduce infant mortality in East Java.

\section{Keywords: health facility, Geographically Weighted Regression, infant mortality, spatial analysis}

\section{Pendahuluan}

Indonesia berusaha menurunkan angka kematian bayi dan balita dalam upaya mewujudkan tujuan pembangunan milenium ke-4 dan dilanjutkan dengan tujuan pembangunan berkelanjutan atau Sustainable Development Goals (SDGs) ke-3. UNICEF menyatakan bahwa pada tahun 1990an Indonesia menunjukkan perkembangan dalam penurunan angka kematian balita bersama dengan komponen-komponennya, angka kematian bayi, dan angka kematian bayi baru lahir. Akan tetapi, dalam beberapa tahun terakhir, penurunan jumlah kematian bayi tampak terhenti. Jika tren ini berlanjut, Indonesia berkemungkinan tidak mencapai target SDGs keempat. Hubungan jumlah kematian bayi dengan faktor-faktor penyebabnya dapat diketahui salah satunya dengan metode analisis regresi. ${ }^{1}$

Jawa Timur merupakan salah satu provinsi dengan tingkat kasus kematian bayi yang tinggi. Berdasarkan laporan kabupaten/kota tahun 2017, angka kematian bayi di Jawa Timur sebesar 23 per 1.000 kelahiran hidup. Angka penyebaran kasus kematian bayi di Jawa Timur yang begitu besar ini salah satunya disebabkan karena lokasi geografis antar wilayah, karena penyebaran kasus kematian bayi sangat dipengaruhi oleh lingkungan sekitar. Jika suatu daerah dengan kasus kematian bayi yang tinggi, maka terdapat kemungkinan bahwa daerah sekitarnya akan memiliki beban kasus kematian bayi yang sama pula. Pendekatan spasial sangat beralasan untuk digunakan pada kasus penyebaran kasus kematian bayi. Oleh karena itu diperlukan suatu metode pemodelan statistik dengan memperhitungkan aspek spasial yaitu menggunakan metode Geographically Weighted Regression (GWR) yang diharapkan mampu menghasilkan model kasus kematian bayi yang tepat di tiap wilayah.

Geographically Weighted Regression
(GWR) adalah salah satu metode spasial yang menggunakan faktor geografis sebagai variabel bebas yang dapat memengaruhi variabel respon. ${ }^{2}$ Aplikasi GWR telah digunakan oleh Afri (2013) menggunakan Model Geographically Weighted Negative Binomial Regression (GWNBR) untuk data kematian bayi pada tahun 2008 di Jawa Timur dan hasilnya menunjukkan bahwa jumlah kematian bayi adalah kejadian langka yang terjadi pada satuan waktu yang satu daerah dengan daerah lainnya memberikan pengaruh yang berbeda. ${ }^{3}$ Selain itu Karyana pada penelitiannya tentang Pemodelan Geografis tentang Angka Kematian Bayi di Jawa Barat menunjukkan hasil pemodelan geografis dengan Geographically Weighted Poisson Regression (GWPR) Model lebih baik menggunakan pendekatan semi parametrik melalui penggunaan beberapa variabel tetap di setiap lokasi dan ada lokal atau berbeda variabel untuk setiap lokasi penelitian. ${ }^{4}$ Penelitian lain yang memperhitungkan aspek lokasi adalah GWPR untuk menganalisis data malnutrisi; hasil menunjukkan bahwa aspek kemiskinan merupakan faktor yang paling memengaruhi jumlah pasien kurang gizi di suatu wilayah dibandingkan dengan aspek kesehatan, pendidikan, dan makanan. ${ }^{5}$ Variabel yang didapat pada penelitian ini melingkupi fasilitas pelayanan kesehatan yang dimiliki setiap kabupaten/kota untuk kesehatan ibu dan anak. Kemudian wilayah yang dipilih untuk penelitian ini adalah kabupaten/kota di Provinsi Jawa Timur karena jumlah pengamatan lebih banyak dan karakteristik pengamatan lebih beragam.

Tujuan yang ingin dicapai yaitu untuk mengetahui faktor eksternal yang menyebabkan kasus kematian bayi di Jawa Timur dengan metode GWR. Manfaat yang diperoleh yaitu sebagai informasi untuk pemerataan sasaran pelaksanaan program pencegahan dan pengendalian dalam rangka menurunkan kasus kematian bayi di Jawa 
Timur serta menambah wawasan peneliti tentang metode spasial khususnya GWR dalam masalah kesehatan ibu dan anak.

\section{Metode}

\section{a. Metode Analisis Data}

\section{Model Regresi Linier}

Metode regresi linier merupakan metode yang memodelkan hubungan antara variabel respon $y$ dan variabel prediktor $x_{1}, x_{2}, \ldots, x_{p} .{ }^{6}$ Model regresi linier secara umum :

$$
y=\beta_{0}+\beta_{1} x_{1}+\beta_{2} x_{2}+\ldots+\beta_{p} x_{p}+\varepsilon
$$

dimana $\beta_{0}, \beta_{1}, \ldots, \beta_{p}$ merupakan parameter model dan $\varepsilon_{i}$ merupakan error yang diasumsikan identik, independen, dan berdistribusi normal dengan mean nol dan varians konstan $\sigma^{2}$ atau $\left(\varepsilon_{i} \sim \operatorname{IIDN}\left(0, \sigma^{2}\right)\right)$. Pada model ini, hubungan antara variabel prediktor dan variabel respon dianggap konstan pada setiap lokasi geografis. Dalam notasi matriks, model regresi dapat dituliskan menjadi sebagai berikut. ${ }^{6}$

$$
\mathbf{y}=\mathbf{X} \boldsymbol{\beta}+\boldsymbol{\varepsilon}
$$

dengan :

$$
\mathbf{y}=\left(\begin{array}{c}
y_{1} \\
y_{2} \\
\vdots \\
y_{n}
\end{array}\right), \mathbf{X}=\left(\begin{array}{lllll}
1 & x_{11} & x_{12} & \cdots & x_{1 p} \\
1 & x_{21} & x_{22} & \cdots & x_{2 p} \\
\vdots & \vdots & \vdots & \ddots & \vdots \\
1 & x_{n 1} & x_{n 2} & \cdots & x_{n p}
\end{array}\right), \boldsymbol{\beta}=\left(\begin{array}{c}
\beta_{0} \\
\beta_{1} \\
\vdots \\
\beta_{p}
\end{array}\right), \quad \boldsymbol{\varepsilon}=\left(\begin{array}{c}
\varepsilon_{1} \\
\varepsilon_{2} \\
\vdots \\
\varepsilon_{n}
\end{array}\right)
$$

\section{Model Geographically Weighted Regression (GWR)}

Model GWR adalah pengembangan dari model regresi di mana setiap parameter dihitung pada setiap titik lokasi, sehingga setiap titik lokasi geografis mempunyai nilai parameter regresi yang berbeda-beda. Model GWR merupakan pengembangan dari model regresi global dimana ide dasarnya diambil dari regresi non parametrik. ${ }^{2}$ Variabel respon $y$ dalam model GWR diprediksi dengan variabel prediktor yang masing-masing koefisien regresinya bergantung pada lokasi dimana data tersebut diamati. Model GWR dapat ditulis sebagai berikut ${ }^{7}$ ini:

$$
y_{i}=\beta_{0}\left(u_{i}, v_{i}\right)+\sum_{k=1}^{p} \beta_{k}\left(u_{i}, v_{i}\right) x_{i k}+\varepsilon_{i}
$$

\section{Keragaman Spasial}

Keragaman spasial adalah fenomena dalam model spasial. Karena keragaman spasial terjadi karena adanya pengaruh dari perbedaan karakteristik wilayah dan letak geografi antar wilayah pengamatan ${ }^{8}$ Variansi spasial ini dapat diketahui dengan menggunakan pengujian BreuschPagan $(B P)^{9}$ dengan observasinya berupa wilayah. Hipotesisnya adalah:

$\mathrm{H}_{0}$ : ragam residual (error) pada model homogen

$\mathrm{H}_{1}$ : ragam residual (error) pada model tidak homogen

Statistik uji Breusch-Pagan (BP) adalah:

$$
B P=\left(\frac{1}{2}\right) \boldsymbol{f}^{T} \boldsymbol{Z}\left(\boldsymbol{Z}^{T} \boldsymbol{Z}\right)^{-\mathbf{1}} \boldsymbol{Z}^{T} \boldsymbol{f} \sim X^{2}{ }_{(p)}
$$

Dengan elemen vektor $\mathbf{f}$ adalah $f=\frac{e_{i}^{2}}{\sigma^{2}}-1$ dimana: $e_{i}^{2}$ least square residual untuk observasi ke-I. $\mathbf{Z}$ adalah matriks berukuran $\mathrm{n} \times(\mathrm{p}+1)$ yang berisi vektor yang sudah dinormalstandarkan $(\mathrm{z})$ untuk setiap observasi Tolak $\mathrm{H}_{0}$ bila $\mathrm{BP}>\chi^{2}(p)$

4. Fungsi Kernel

Peran pembobot pada model GWR sangat penting karena nilai pembobot ini mewakili letak data observasi satu dengan lainnya. Fungsi kernel digunakan untuk mengestimasi paramater dalam model GWR jika fungsi jarak $\left(w_{j}\right)$ adalah fungsi yang kontinu dan monoton turun. ${ }^{2}$ Pembobot yang terbentuk dengan menggunakan fungsi kernel ini adalah fungsi jarak Gaussian (Gaussian Distance Function), fungsi Exponential, fungsi Bisquare, dan fungsi kernel Tricube. Fungsi pembobot yang digunakan pada penelitian ini adalah fungsi jarak Gaussian $^{7}$ :

$$
w_{j}\left(u_{i}, v_{i}\right)=\exp \left[-\frac{1}{2}\left(d_{i j} / h\right)^{2}\right]
$$

dengan $\quad d_{i j}=\sqrt{\left(u_{i}-u_{j}\right)^{2}+\left(v_{i}-v_{j}\right)^{2}} \quad$ adalah jarak eucliden antara lokasi $\left(u_{i}, v_{i}\right)$ ke lokasi $\left(u_{j}, v_{j}\right)$ dan $h$ adalah parameter non negatif yang diketahui dan biasanya disebut parameter penghalus (bandwidth).

Bandwidth dapat dianalogikan sebagai radius dari suatu lingkaran, sehingga sebuah titik yang berada di dalam radius lingkaran masih dianggap memiliki pengaruh. Di dalam pembentukan sebuah model GWR, bandwidth berperan sangat penting 
karena akan berpengaruh pada ketepatan model terhadap data, yaitu mengatur varians dan bias dari model. Ada beberapa metode yang digunakan untuk memilih bandwidth optimum, salah satu diantaranya adalah metode Cross Validation atau CV yang secara matematis didefinisikan sebagai berikut:

dengan $\hat{y}_{\neq i}(h)$ adalah nilai penaksir $y_{i}$ dimana

$$
C V(h)=\sum_{i=1}^{n}\left(y_{i}-\hat{y}_{\neq i}(h)\right)^{2}
$$

pengamatan di lokasi $\left(u_{i}, v_{i}\right)$ dihilangkan dari proses estimasi. Untuk mendapatkan nilai $h$ yang optimal maka diperoleh dari $h$ yang menghasilkan nilai $\mathrm{CV}$ yang minimum.

\section{Pengujian Hipotesis Model GWR}

Terdiri dari pengujian kesesuaian model GWR dan pengujian parameter model. Hipotesis uji kesesuaian model GWR: $\mathrm{H}_{0}: \beta_{k}\left(u_{i}, v_{i}\right)=\beta_{k}$ untuk setiap $k=0,1,2, \cdots, p$, dan $i=1,2, \cdots, n$ (tidak ada perbedaan yang signifikan antara model regresi global dan GWR)

$\mathrm{H}_{1}$ : Paling sedikit ada satu

$\beta_{k}\left(u_{i}, v_{i}\right) \neq \beta_{k}, k=0,1,2, \cdots, p$

(ada perbedaan signifikan antara model regresi global dan GWR)

Statistik uji :

Adapun pengujian signifikansi parameter model

$$
F_{\text {himmg }}=\frac{\operatorname{RSS}\left(H_{1}\right) /\left(\frac{\delta_{1}^{2}}{\delta_{2}}\right)}{\operatorname{RSS}\left(H_{0}\right) /(n-p-1)}
$$

pada setiap lokasi dilakukan dengan menguji parameter secara parsial. Hipotesisnya :

$\mathrm{H}_{0}: \beta_{k}\left(u_{i}, v_{i}\right)=0$

$H_{1}: \beta_{k}\left(u_{i}, v_{i}\right) \neq 0$ dengan $k=1,2, \cdots, p$

Statistik uji yang digunakan :

$$
T_{h i t}=\frac{\hat{\beta}_{k}\left(u_{i}, v_{i}\right)}{\hat{\sigma} \sqrt{c_{k k}}}
$$

\section{Pemilihan Model Terbaik}

Ada beberapa metode yang digunakan untuk memilih model terbaik, salah satunya yaitu Akaike's Information Criterion (AIC) yang didefinisikan sebagai berikut :

$$
\operatorname{AIC}(h)=\mathrm{D}(h)+2 \mathrm{~K}(h)
$$

Keterangan:

$y_{i}$ : Nilai observasi variabel respon untuk lokasi ke-i $\left(u_{i}, v_{i}\right)$ : Menyatakan titik koordinat (longitude, latitude) lokasi $i$ $\beta_{k}\left(u_{i}, v_{i}\right)$ : Koefisien regresi variabel prediktor ke- $k$ untuk lokasi ke- $i$
$\mathrm{D}(h)$ merupakan nilai devians model dengan lebar jendela $(h)$ dan $\mathrm{K}(h)$ merupakan jumlah parameter dalam model dengan lebar jendela $(h)^{2}$. $\operatorname{AIC}(h)$ digunakan karena kompleksitas dari model yaitu perbedaan nilai pengamatan dengan nilai dugaan, $\operatorname{AIC}(h)$ juga tergantung pada variabel dalam model serta nilai lebar jendela. Model terbaik adalah model dengan nilai AIC terkecil.

\section{b. Sumber Data dan Variabel Penelitian}

Pada penelitian ini digunakan data sekunder yang diperoleh dari Dinas Kesehatan Provinsi Jawa Timur dan Badan Pusat Statistika Provinsi Jawa Timur tahun 2018. Observasi pada penelitian ini adalah kabupaten dan kota di Provinsi Jawa Timur sebanyak 38. Adapun variabel penelitian yang digunakan pada penelitian ini digambarkan pada Tabel 1.

\section{c. Langkah Analisis}

Tahapan analisis yang digunakan untuk menjawab tujuan dari penelitian sebagai berikut:

1. Melakukan analisis deskriptif.

2. Memodelkan kasus kematian bayi dengan metode regresi linier global atau metode Ordinary Least Square (OLS).

Melakukan uji asumsi model regresi klasik bahwa residual bersifat IIDN (Identik, Independen dan berdistribusi normal)

3. Sedangkan tahapan dalam model spasial menggunakan GWR antara lain:

a. Menentukan nilai bandwidth optimum berdasarkan kriteria Cross Validation (CV). Perhitungan CV dilakukan hingga mendapatkan nilai CV minimum.

b. Menentukan matriks pembobot dengan menggunakan fungsi kernel Gaussian.

c. Menaksir parameter model GWR dengan menggunakan bandwidth optimum.

4. Membandingkan hasil antara regresi OLS dan GWR menggunakan kriteria $\mathrm{R}^{2}$ dan SSE.

a. Uji kesesuaian model untuk melihat apa faktor geografi berpengaruh terhadap kejadian kematian bayi.

b. Menguji signifikansi parameter secara parsial.

5. Menginterpretasi dan menyimpulkan hasil yang diperoleh. 
Tabel 1. Variabel Penelitian

\begin{tabular}{|c|c|c|c|}
\hline \multicolumn{2}{|r|}{ Variabel } & \multirow{2}{*}{$\begin{array}{l}\text { Keterangan } \\
\text { Jumlah kasus kematian bayi lahir hidup di bawah usia lima } \\
\text { tahun }\end{array}$} & \multirow{2}{*}{\begin{tabular}{l}
\multicolumn{1}{c}{ Sumber } \\
Dinas Kesehatan \\
Provinsi Jawa \\
Timur, Profil \\
Kesehatan $^{10}$
\end{tabular}} \\
\hline$(\mathrm{Y})$ & Jumlah Kematian Bayi & & \\
\hline$\left(\mathrm{X}_{1}\right)$ & $\begin{array}{l}\text { Jumlah Posyandu Strata } \\
\text { Pratama }\end{array}$ & $\begin{array}{l}\text { Posyandu yang belum mantap, yang ditandai oleh kegiatan } \\
\text { bulanan Posyandu belum terlaksana secara rutin serta jumlah } \\
\text { kader sangat terbatas yakni kurang dari } 5 \text { (lima) orang. }\end{array}$ & $\begin{array}{l}\text { Dinas Kesehatan } \\
\text { Provinsi Jawa } \\
\text { Timur, Profil } \\
\text { Kesehatan }^{10}\end{array}$ \\
\hline$\left(\mathrm{X}_{2}\right)$ & $\begin{array}{l}\text { Jumlah Posyandu Strata } \\
\text { Madya }\end{array}$ & $\begin{array}{l}\text { Posyandu yang sudah dapat melaksanakan kegiatan lebih dari } \\
8 \text { kali per tahun, dengan rata-rata jumlah kader sebanyak lima } \\
\text { orang atau lebih, tetapi cakupan kelima kegiatan utamanya } \\
\text { masih rendah, yaitu kurang dari } 50 \%\end{array}$ & $\begin{array}{l}\text { Dinas Kesehatan } \\
\text { Provinsi Jawa } \\
\text { Timur, Profil } \\
\text { Kesehatan }^{10}\end{array}$ \\
\hline$\left(\mathrm{X}_{3}\right)$ & $\begin{array}{l}\text { Jumlah Posyandu Strata } \\
\text { Purnama }\end{array}$ & $\begin{array}{l}\text { Posyandu yang sudah dapat melaksanakan kegiatan lebih dari } \\
8 \text { kali per tahun, dengan rata-rata jumlah kader sebanyak lima } \\
\text { orang atau lebih, cakupan kelima kegiatan utamanya lebih dari } \\
50 \% \text {, mampu menyelenggarakan program tambahan, serta } \\
\text { telah memperoleh sumber pembiayaan dari dana sehat yang } \\
\text { dikelola oleh masyarakat yang pesertanya masih terbatas yakni } \\
\text { kurang dari } 50 \% \text { KK di wilayah kerja Posyandu. }\end{array}$ & $\begin{array}{l}\text { Dinas Kesehatan } \\
\text { Provinsi Jawa } \\
\text { Timur, Profil } \\
\text { Kesehatan }^{10}\end{array}$ \\
\hline$\left(\mathrm{X}_{4}\right)$ & $\begin{array}{l}\text { Jumlah Posyandu Strata } \\
\text { Mandiri }\end{array}$ & $\begin{array}{l}\text { Posyandu Mandiri adalah Posyandu yang sudah dapat } \\
\text { melaksanakan kegiatan lebih dari } 8 \text { kali per tahun, dengan } \\
\text { rata-rata jumlah kader sebanyak lima orang atau lebih, } \\
\text { cakupan kelima kegiatan utamanya lebih dari } 50 \% \text {, mampu } \\
\text { menyelenggarakan program tambahan, serta telah memperoleh } \\
\text { sumber pembiayaan dari dana sehat yang dikelola oleh } \\
\text { masyarakat yang pesertanya lebih dari } 50 \% \text { KK yang } \\
\text { bertempat tinggal di wilayah kerja } \\
\text { Posyandu. }\end{array}$ & $\begin{array}{l}\text { Dinas Kesehatan } \\
\text { Provinsi Jawa } \\
\text { Timur, Profil } \\
\text { Kesehatan }^{10}\end{array}$ \\
\hline$\left(\mathrm{X}_{5}\right)$ & Jumlah Klinik KB (KKB) & Sarana pelayanan kontrasepsi termasuk program KB & $\begin{array}{l}\text { BPS, Statistika } \\
\text { Kesehatan }^{11}\end{array}$ \\
\hline$\left(\mathrm{X}_{6}\right)$ & $\begin{array}{l}\text { Jumlah Pos Pelayanan } \\
\text { Keluarga Berencana Desa } \\
\text { (PPKBD) }\end{array}$ & $\begin{array}{l}\text { Sarana pembinaan dan pelayanan keluarga berencana melalui } \\
\text { sistim kelompok-kelompok akseptor keluarga berencana. }\end{array}$ & $\begin{array}{l}\text { BPS, Statistika } \\
\text { Kesehatan }^{11}\end{array}$ \\
\hline$\left(\mathrm{X}_{7}\right)$ & $\begin{array}{l}\text { Jumlah Desa/Kelurahan } \\
\text { Yang Memiliki Rumah } \\
\text { Sakit Bersalin }\end{array}$ & $\begin{array}{l}\text { Rumah sakit yg khusus melayani pemeriksaan ibu hamil, ibu } \\
\text { yg akan melahirkan, dan kesehatan anak di bawah usia lima } \\
\text { tahun }\end{array}$ & $\begin{array}{l}\text { BPS, Statistika } \\
\text { Kesehatan }^{12}\end{array}$ \\
\hline$\left(\mathrm{X}_{8}\right)$ & $\begin{array}{l}\text { Jumlah Desa/Kelurahan } \\
\text { Yang Memiliki Puskesmas } \\
\text { Pembantu }\end{array}$ & $\begin{array}{l}\text { Puskesmas Pembantu (pustu) adalah fasilitas untuk menunjang } \\
\text { dan membantu melaksanakan kegiatan yang dilakukan } \\
\text { Puskesmas }\end{array}$ & $\begin{array}{l}\text { BPS, Statistika } \\
\text { Kesehatan }^{12}\end{array}$ \\
\hline$\left(\mathrm{X}_{9}\right)$ & $\begin{array}{l}\text { Jumlah Desa/Kelurahan } \\
\text { Yang Memiliki Apotek }\end{array}$ & $\begin{array}{l}\text { Toko tempat meramu dan menjual obat berdasarkan resep } \\
\text { dokter serta memperdagangkan barang medis; rumah obat }\end{array}$ & $\begin{array}{l}\text { BPS, Statistika } \\
\text { Kesehatan }^{12}\end{array}$ \\
\hline
\end{tabular}

\section{Hasil}

\section{a. Gambaran Umum Kondisi Jumlah Kematian Bayi di Provinsi Jawa Timur}

Dari Gambar 1, dapat diketahui bahwa jumlah kematian bayi di Jawa Timur pada tahun 2018 mencapai 4.016 jiwa yang meliputi seluruh kabupaten dan kota. Jumlah kematian bayi paling banyak berada di wilayah Kabupaten Probolinggo dengan jumlah kematian bayi mencapai 242 jiwa, yakni $6,03 \%$ kematian bayi di Jawa Timur, disusul Kota Surabaya dengan jumlah kematian bayi 214 jiwa (5,33\%) dan Kabupaten Jombang 199 jiwa atau 4,96 persen. Kematian bayi di Jawa Timur paling sedikit berada di wilayah Kota Mojokerto dengan 


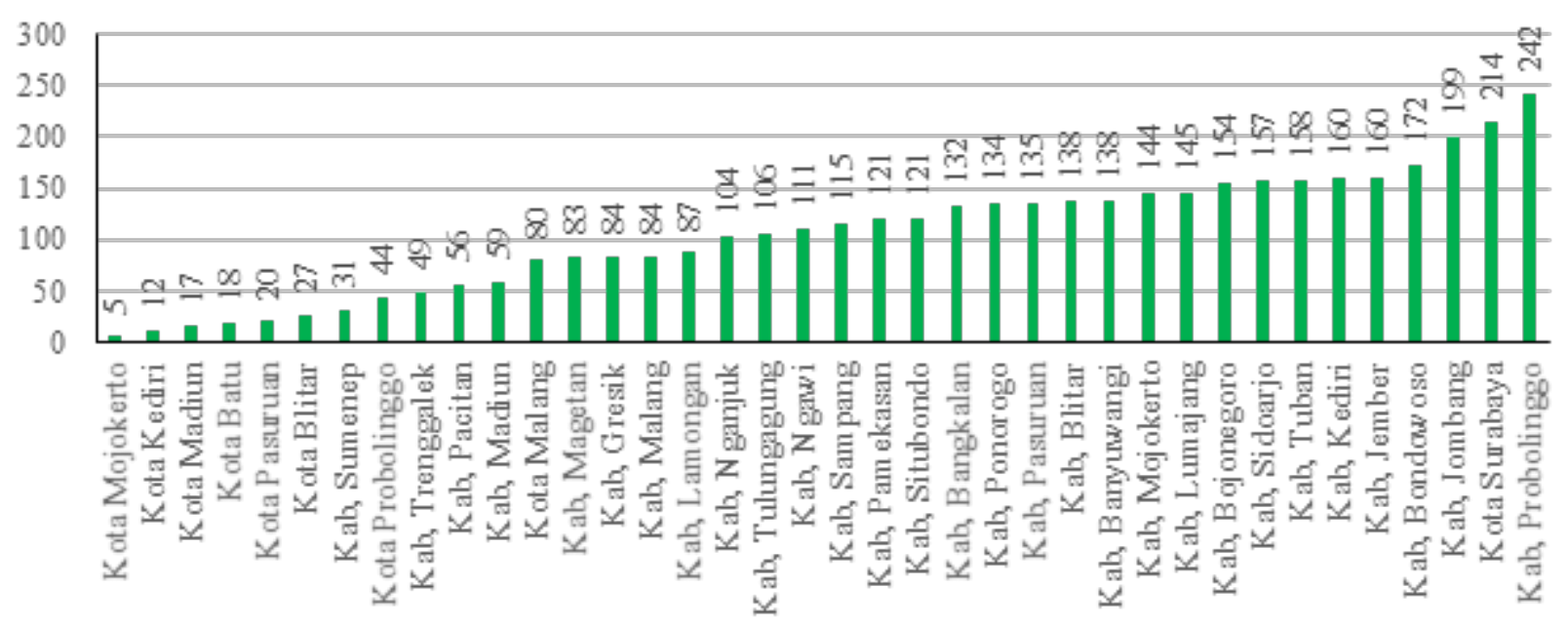

\section{Gambar 1. Variabel Penelitian}

jumlah kematian bayi mencapai 5 jiwa atau $0,12 \%$ kematian bayi di Jawa Timur.

\section{b. Pemodelan Regresi Linier}

Model regresi linier dapat digunakan untuk melihat hubungan antara jumlah kematian bayi di setiap kabupaten/kota di Provinsi Jawa Timur dengan faktor-faktor yang diduga memengaruhi. Variabel prediktor yang digunakan dalam model regresi tidak saling multikolinearitas. Penelitian ini menggunakan nilai Variance Inflation Factors (VIF) sebagai kriteria untuk mengetahui adanya multikolinearitas antar variabel prediktor. Nilai VIF yang lebih besar dari 10 menunjukkan adanya kolinearitas antar variabel prediktor.

Tabel 2 menunjukkan antar variabel prediktor tidak saling berkorelasi, sehingga semua variabel prediktor yang diduga memengaruhi jumlah kematian bayi di Provinsi Jawa Timur dapat digunakan dalam pembentukan model regresi linier. Pengujian parameter secara serentak merupakan pengujian secara bersama semua variabel prediktor dalam model regresi. Pengujian regresi linier dilakukan regresi terhadap variabel respon jumlah kematian bayi sehingga diperoleh model sebagai berikut:

Hipotesis yang digunakan untuk menyusun model

$\begin{aligned} \hat{y}= & 48.335318-0.340954 X_{1}+0.108640 \mathrm{X}_{2}+0.046079 \mathrm{X}_{3}-0.138504 \mathrm{X}_{4}-0.002292 \mathrm{X}_{5}+0.124366 \mathrm{X}_{6} \\ & +0.111688 \mathrm{X}_{7}-0.304629 \mathrm{X}_{8}+0.048175 \mathrm{X}_{9}\end{aligned}$

regresi linier nya adalah sebagai berikut.

$H_{0}: \beta_{1}=\beta_{2}=\beta_{3}=\beta_{4}=\beta_{5}=\beta_{6}=\beta_{7}=\beta_{8}=\beta_{9}=0$

$H_{1}$ : minimal ada satu $\beta_{k} \neq 0$

Tabel 3 menunjukkan hasil pengujian secara serentak model regresi OLS dengan taraf signifikansi sebesar $10 \%$ keputusan menolak $\mathrm{H}_{0}$ karena nilai $F_{\text {hitung }}=4.247$ lebih besar dari nilai tabel statistik dengan derajat kebebasan (degree of freedom $/ d f) F_{(0,1 ; ; ; 28)}=1,865$ dan $p$-value $=0,002$ $<0,1$. Sehingga disimpulkan minimal ada salah satu variabel prediktor yang memengaruhi variabel respon jumlah kematian bayi di Provinsi Jawa Timur. Nilai koefisien determinasi $\left(\mathrm{R}^{2}\right)$ adalah $44,13 \%$ yang berarti bahwa model regresi dapat menjelaskan variabilitas kejadian jumlah kematian bayi sebesar $44,13 \%$ sedangkan sisanya $55,87 \%$ dijelaskan oleh variabel lainnya di luar model.

Tabel 2. Nilai VIF Variabel Prediktor yang Diduga Memengaruhi Jumlah Kematian Bayi di Provinsi Jawa Timur

\begin{tabular}{cccccccccc}
\hline & $\mathbf{X}_{\mathbf{1}}$ & $\mathbf{X}_{\mathbf{2}}$ & $\mathbf{X}_{\mathbf{3}}$ & $\mathbf{X}_{\mathbf{4}}$ & $\mathbf{X}_{\mathbf{5}}$ & $\mathbf{X}_{\mathbf{6}}$ & $\mathbf{X}_{\mathbf{7}}$ & $\mathbf{X}_{\mathbf{8}}$ & $\mathbf{X}_{\mathbf{9}}$ \\
\cline { 2 - 10 } Nilai VIF & 2.754 & 2,922 & 5,180 & 2,897 & 3,989 & 3,168 & 3,290 & 2,221 & 4,605 \\
\hline
\end{tabular}


Tabel 3. Hasil Uji Serentak Regresi Linear

\begin{tabular}{ccccc}
\hline $\boldsymbol{D} \boldsymbol{f}$ & $\mathbf{F}_{\text {-hitung }}$ & $\mathbf{F}_{\text {tabel }}$ & $\boldsymbol{P}_{\text {value }}$ & $\mathrm{R}^{2}$ \\
\hline $9 ; 28$ & 4.247 & 3,981 & $0.002^{*}$ & 44,13 \\
\hline
\end{tabular}

\section{c. Model Geographically Weighted Regression (GWR)}

Model GWR adalah pengembangan dari model regresi dimana setiap parameter dihitung pada setiap titik lokasi, sehingga setiap titik lokasi geografis mempunyai nilai parameter regresi yang berbeda-beda. Tahapan penyusunan Model GWR adalah sebagai berikut:

\section{Uji Heteroskedastisitas}

Diagnosis ini untuk mengetahui apakah ada heterogenitas spasial. Hal ini penting dilakukan untuk menentukan tindakan selanjutnya, yaitu menentukan model spasial manakah yang akan digunakan untuk memodelkan kematian bayi di Jawa Timur. Uji Heteroskedastisitas dilakukan untuk mengetahui kehomogenan ragam pada residual dengan uji yang digunakan adalah BreuschPagan. Model GWR dikatakan baik apabila terdapat heteroskedastisitas. Hasil pengujian dapat dilihat pada Tabel 4.

Tabel 4. Uji Heteroskedastisitas

\begin{tabular}{ccc}
\hline$d f$ & $\begin{array}{c}\text { Breusch-Pagan } \\
\text { Value }\end{array}$ & P-value \\
\hline 9 & 15,6645 & 0,07423 \\
\hline
\end{tabular}

Dari tabel 4 dapat diketahui bahwa diperoleh p-value sebesar 0,07423 yang lebih kecil dari $\alpha$ $(10 \%=0.1)$, maka keputusannya adalah menolak hipotesis $\mathrm{HO}$ yang berarti ragam residual (error) pada model tidak homogen. Untuk mengatasi masalah heterogenitas spasial dalam model regresi linier, maka digunakan metode GWR.

\section{Pemilihan Bobot Optimum}

Model GWR menggunakan pembobot berdasarkan letak geografis setiap kabupaten/ kota. Langkah pertama yang dilakukan adalah dengan menentukan letak geografis (longitude dan latitude) tiap kabupaten/kota di Provinsi Jawa Timur, selanjutnya menghitung jarak euclidean berdasarkan letak geografis untuk setiap kabupaten/ kota di Provinsi Jawa Timur. Suatu wilayah dapat ditentukan urutan wilayah-wilayah lain yang berdekatan berdasarkan jarak euclidean sehingga akan didapatkan urutan tetangga terdekat untuk seluruh wilayah pengamatan. Berikutnya memilih bandwith optimum untuk setiap kabupaten/kota dengan fungsi kernel. Untuk memilih metode kernel terbaik, dilakukan pembuatan model untuk masingmasing pembobot untuk mendapatkan nilai Cross Validation (CV) dari pembobot. Pembobot dengan nilai $\mathrm{CV}$ paling kecil digunakan sebagai pembobot terbaik untuk membangun model. Pada Tabel 5 dapat dilihat hasil CV masing-masing pembobot. Pemilihan pembobot optimum dengan menggunakan kriteria nilai CV dari tiap-tiap pembobot.

\section{Tabel 5. Pemilihan Pembobot Optimum melalui} Cross Validation

\begin{tabular}{lc}
\hline \multicolumn{1}{c}{ Pembobot Kernel } & Cross Validation $(\boldsymbol{C V})$ \\
\hline Adaptive Gaussian & $134.954,8^{*}$ \\
Adaptive bi-square & $141.939,1$ \\
Fixed Gaussian & $136.699,8$ \\
Fixed bi-square & $156.795,5$ \\
\hline
\end{tabular}

*Nilai Bandwith optimum karena nilai CV paling minimum

Pembobot dapat dikatakan optimum apabila nilai CV yang kecil. Tabel 5 menunjukkan bahwa bandwith Adaptive Gaussian merupakan pembobot optimum untuk dilakukan pemodelan GWR karena memiliki nilai $\mathrm{CV}$ yang lebih kecil dibanding pembobot lainnya.

\section{Pengujian Model GWR secara Serentak}

Pengujian model GWR dilakukan dengan tujuan untuk mengetahui adanya pengaruh faktor lokasi di kabupaten/kota terhadap kejadian kematian bayi di Provinsi Jawa Timur. Hipotesis yang digunakan untuk menyusun model GWR adalah sebagai berikut:

$H_{0}: \beta_{k}\left(u_{1}, v_{1}\right)=\beta_{k}\left(u_{2}, v_{2}\right)=\ldots . .=\beta_{k}\left(u_{8}, v_{8}\right)=\beta_{k}$ $H_{1}$ : minimal ada satu $\beta_{k}\left(u_{i}, v_{i}\right) \neq \beta_{k}$

Tabel 6 menunjukkan taraf signifikansi ( $\alpha$ ) sebesar $10 \%$ keputusan gagal menolak $\mathrm{H}_{0}$ karena nilai $F_{I}=0,6453$ lebih kecil $F_{(0,1 ; 8 ; 28)}=1,9$. Sehingga disimpulkan tidak terdapat perbedaan yang signifikan antara model GWR dan model linier. 
Tabel 6. Hasil Pengujian Model GWR

\begin{tabular}{lcccc}
\hline \multicolumn{1}{c}{$\begin{array}{c}\text { Estimasi } \\
\text { Model }\end{array}$} & SSE & Df & F & P-value \\
\hline Model GWR & 56140.932 & 28 & 0,6453 & 0,256 \\
Model Regresi & 6000.782 & 8 & & \\
\hline
\end{tabular}

\section{Pemilihan Model Terbaik}

Model regresi terbaik dipilih dengan melihat besarnya nilai kebaikan model. Kebaikan suatu model dapat dilihat dari nilai R2 yang dihasilkan. Nilai R2 yang lebih besar dibandingkan model lainnya menunjukkan bahwa model tersebut lebih baik dibandingkan model lainnya. Tabel 7 menunjukkan ukuran kebaikan model yang dihasilkan oleh model regresi linier dan GWR.

\section{Tabel 7. Pemilihan Model Terbaik}

\begin{tabular}{lc}
\hline \multicolumn{1}{r}{ Model } & $\mathbf{R}^{2}$ \\
\hline Regresi Linier & $44,13 \%$ \\
GWR & $95.48 \%$ \\
\hline
\end{tabular}

Tabel 7 menunjukkan nilai R2 secara keseluruhan untuk model OLS dan GWR. Secara keseluruhan nilai R2 yang dihasilkan oleh model GWR lebih besar dibandingkan model regresi linier. Hal ini menunjukkan bahwa model GWR lebih baik digunakan dalam memodelkan kasus kematian bayi di Provinsi Jawa Timur.

\section{Pembahasan}

Berdasarkan hasil analisis, variabel fasilitas kesehatan berpengaruh terhadap kasus kematian bayi selain itu faktor lokasi juga memengaruhinya, hal ini dikarenakan adanya efek spasial seperti ditunjukkan pada Gambar 2.

Model GWR lebih baik digunakan untuk memodelkan kasus kematian bayi di Provinsi
Jawa Timur seperti pembahasan pada Tabel 7 dibandingkan model regresi linier karena keragaman spasial merupakan data spasial proses nonstasioner dengan ragam bervariasi antar wilayah pengamatan. Parameter yang dihasilkan pada model GWR bersifat lokal di setiap wilayah tempat data tersebut diamati. Faktor-faktor yang memengaruhi kasus kematian bayi secara spasial sesuai dengan kekurangan yang mendominasi di wilayah tersebut. Indikator fasilitas kesehatan yang berbeda akan memengaruhi kebijakan yang diberikan kepada masing-masing wilayah. Oleh karena itu dilakukan uji parsial untuk setiap parameter di setiap wilayah pengamatan. Uji parameter model GWR secara parsial menggunakan statistik uji t. Pengujian signifikansi parameter model menggunakan hipotesis sebagai berikut:

$\mathrm{H}_{0}: \beta_{k}\left(\mathrm{u}_{\mathrm{i}}, \mathrm{vi}\right)=0$

$\mathrm{H}_{1}: \beta_{k}\left(\mathrm{u}_{\mathrm{i}}, \mathrm{vi}\right) \neq \beta_{\mathrm{k}} ; \mathrm{i}=1,2, \ldots, 38, \mathrm{k}=1,2,3,9$

Pada taraf signifikansi $(\alpha) 10 \%$, diperoleh nilai $\left.\mathrm{t}_{0,05 ; 28}\right)=2,045$. Berikut ini disajikan pengelompokan berdasarkan variabel yang signifikan.

Berikut merupakan hasil pemetaan dari Tabel 8 .

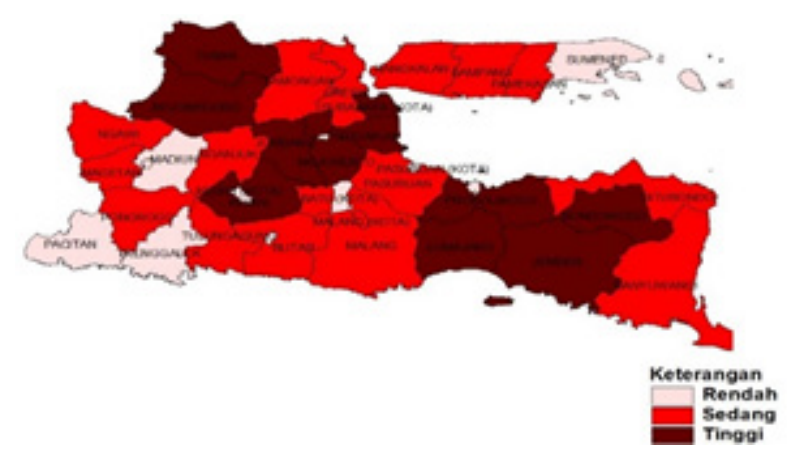
Gambar 2. Visualisasi Wilayah berdasarkan
Kasus Kematian Bayi

Tabel 8. Faktor yang Memengaruhi Kematian Bayi pada Setiap Wilayah

\begin{tabular}{cl}
\hline Variabel yang Signifikan & \multicolumn{1}{c}{ Kabupaten/Kota } \\
\hline $\mathrm{X}_{1}, \mathrm{X}_{2}, \mathrm{X}_{8}$ & Pacitan, Ponorogo, Pasuruan, Kediri (Kota), Malang (Kota), Pasuruan \\
$\mathrm{X}_{1}, \mathrm{X}_{2}$ & (Kota), Banyuwangi, Probolinggo \\
$\mathrm{X}_{3}, \mathrm{X}_{4}$ & Bondowoso, Bangkalan, Batu (Kota), Blitar, Sidoarjo, Sumenep \\
$\mathrm{X}_{3}$ & Lamongan, Madiun (Kota), Kediri, Malang \\
$\mathrm{X}_{1}$ & Lumajang, Jombang, Magetan, Bojonegoro, Jember \\
\hline
\end{tabular}




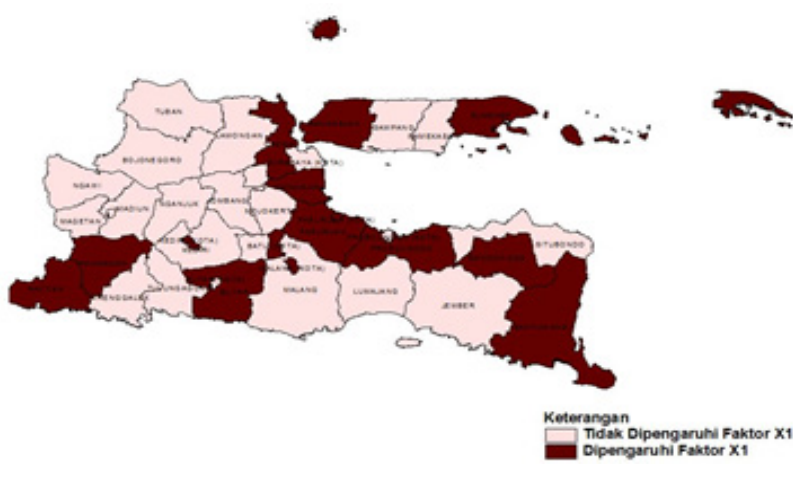

Gambar 3. Visualisasi Wilayah berdasarkan Pengaruh Signifikansi Faktor Jumlah Posyandu Strata Pratama $\left(\mathbf{X}_{1}\right)$

Gambar 3 menjelaskan bahwa terdapat 15 wilayah di Provinsi Jawa Timur yang kasus kematian bayinya dipengaruhi oleh ketersediaan posyandu strata pratama. Wilayah tersebut adalah Kab. Pacitan, Ponorogo, Bondowoso, Pasuruan, Bangkalan, Blitar, Banyuwangi, Gresik, Probolinggo, Sidoarjo, Sumenep, Kota Kediri, Malang, Pasuruan, dan Kota Batu.

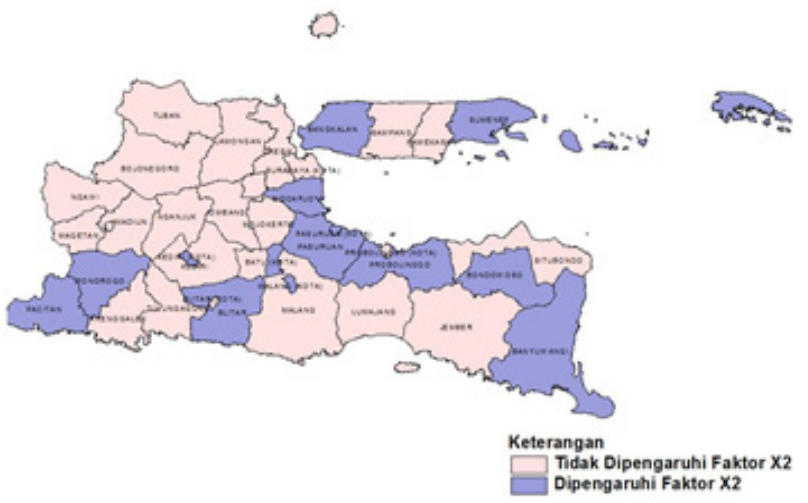

Gambar 4. Pemetaan Wilayah berdasarkan Pengaruh Signifikansi Faktor Jumlah Posyandu Strata Madya $\left(\mathbf{X}_{2}\right)$

Gambar 4 menjelaskan bahwa terdapat 14 wilayah di Provinsi Jawa Timur yang kasus kematian bayinya dipengaruhi oleh ketersediaan posyandu strata madya. Wilayah tersebut adalah Kab. Pacitan, Ponorogo, Bondowoso, Pasuruan, Bangkalan, Blitar, Banyuwangi, Probolinggo, Sidoarjo, Sumenep, Kota Kediri, Malang, Pasuruan, dan Kota Batu.

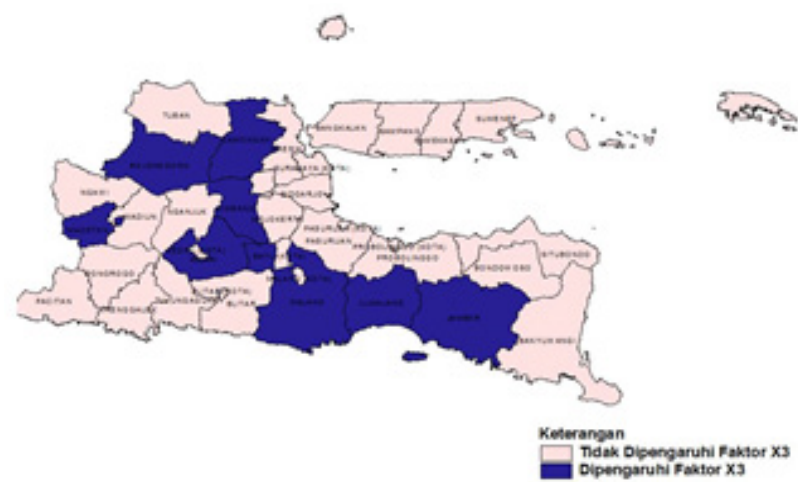

Gambar 5. Pemetaan Wilayah berdasarkan Pengaruh Signifikansi Faktor Jumlah Posyandu Strata Purnama $\left(\mathbf{X}_{3}\right)$

Gambar 5 menjelaskan bahwa terdapat sembilan wilayah di Provinsi Jawa Timur yang kasus kematian bayinya dipengaruhi oleh ketersediaan posyandu strata purnama. Wilayah tersebut adalah Kabupaten Lumajang, Jombang, Magetan, Bojonegoro, Lamongan, Kediri, Jember, Malang, dan Kota Madiun.

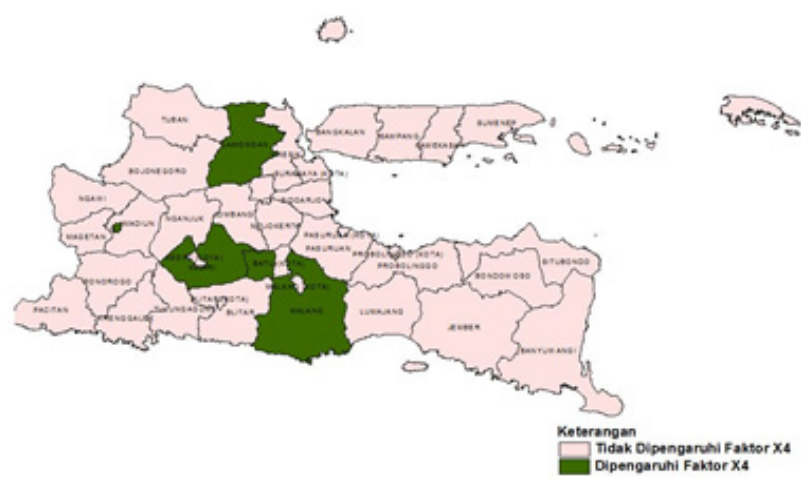

\section{Gambar 6. Pemetaan Wilayah berdasarkan Pengaruh Signifikansi Faktor Jumlah Posyandu Strata Mandiri $\left(\mathbf{X}_{4}\right)$}

Gambar 6 menjelaskan bahwa terdapat empat wilayah di Provinsi Jawa Timur yang kasus kematian bayinya dipengaruhi oleh ketersediaan posyandu strata mandiri. Wilayah tersebut adalah Kabupaten Lamongan, Kediri, Malang, dan Kota Madiun

Gambar 7 menjelaskan bahwa terdapat delapan wilayah di Provinsi Jawa Timur yang kasus 


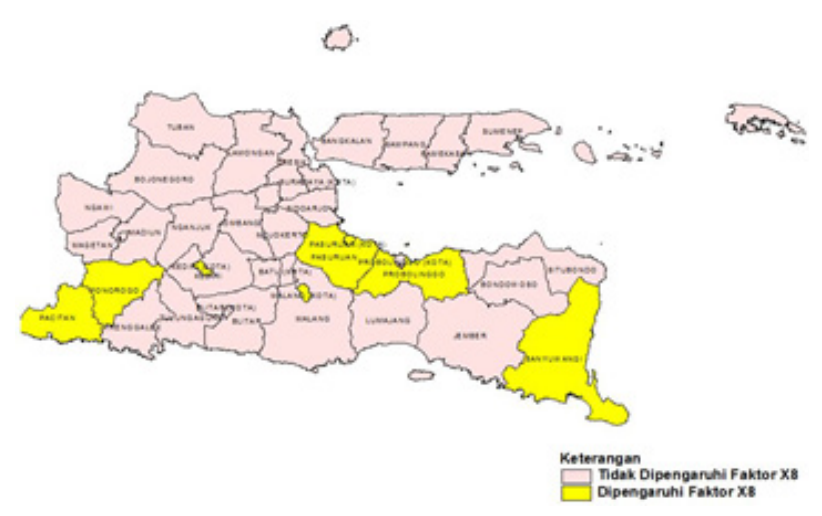

Gambar 7. Pemetaan Wilayah berdasarkan Pengaruh Signifikansi Faktor Jumlah Desa/Kelurahan yang Memiliki Puskesmas Pembantu $\left(\mathbf{X}_{8}\right)$

kematian bayinya dipengaruhi oleh ketersediaan puskesmas pembantu. Wilayah tersebut adalah Kab. Pacitan, Ponorogo, Pasuruan, Banyuwangi, Probolinggo, Kota Kediri, Malang, dan Kota Pasuruan.

Gambar 8 menjelaskan bahwa terdapat 14 wilayah di Provinsi Jawa Timur yang kasus kematian bayinya tidak dipengaruhi oleh faktor apapun didalam model GWR yang telah terbentuk. Hal ini mengindikasikan bahwa wilayah tersebut dipengaruhi oleh efek lokasi dan faktor lain di luar faktor yang digunakan pada penelitian ini. Wilayah tersebut adalah Kota Blitar, Mojokerto, Probolinggo, Surabaya, Kabupaten Madiun, Mojokerto, Nganjuk, Ngawi, Pamekasan, Sidoarjo, Sumenep, Trenggalek, Tuban, dan Kabupaten Tulungagung.

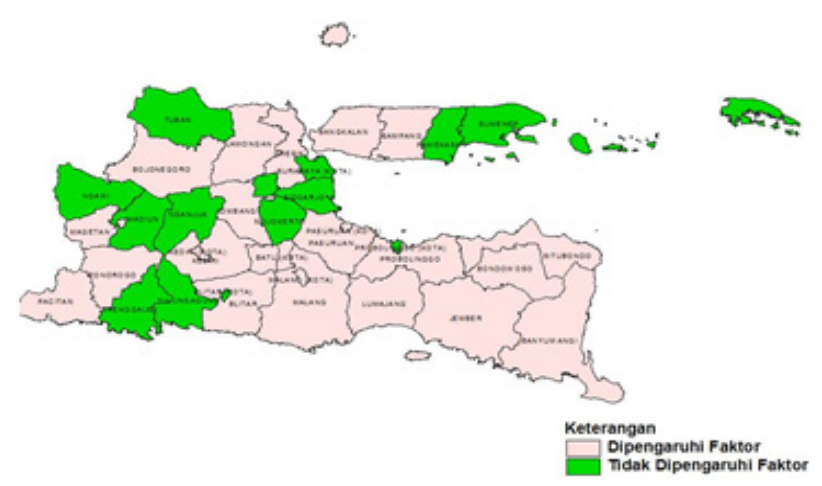

Gambar 8. Pemetaan Wilayah yang Tidak Dipengaruhi oleh Faktor Fasilitas Kesehatan

\section{Kesimpulan}

Analisis menunjukkan bahwa terdapat perbedaan yang signifikan dari faktor ketersediaan fasilitas kesehatan terhadap kejadian kematian bayi di setiap kabupaten/kota Provinsi Jawa Timur. Ketersediaan posyandu untuk segala strata merupakan fasilitas kesehatan yang paling banyak memengaruhi kejadian kematian bayi di Jawa Timur selain ketersediaan puskesmas pembantu. Sedangkan adanya klinik KB, Pos Pelayanan Keluarga Berencana Desa (PPKBD), rumah sakit bersalin dan apotek tidak memengaruhi kejadian kematian bayi di setiap wilayah di Jawa Timur.

\section{Saran}

Tingginya kejadian kematian bayi di Jawa Timur ini sebenarnya dapat ditekan bila ketersediaan fasilitas kesehatan penunjang terjamin, ada kesadaran ibu untuk menjaga kesehatan diri dan asupan nutrisi untuk bayi, serta rutin mengecek kesehatan. Semua itu merupakan salah satu upaya untuk menekan tingkat kematian bayi di Jawa Timur.

\section{Ucapan Terima Kasih}

Penulis mengucapkan terima kasih kepada Program Studi Statistika Universitas PGRI Adi Buana Surabaya yang telah memberikan izin untuk membuat artikel.

\section{Daftar Rujukan}

1. Ramadhan RF, Kurniawan R. Pemodelan Data Kematian Bayi dengan Geographically Weighted Negative Binomial Regression. Media Statistika. 2016; 9(2): 95-106.

2. Fotheringham AS, Brunsdon C, Charlton M. Geographically Weighted Regression: The Analysis of Spatially Varying Relationships. West Sussex, England: John Wiley \& Sons, Ltd.; 2002.

3. Afri LE. Model Regresi Binomial Negatif Terboboti Geografis untuk Data Kematian Bayi. Jurnal Ilmiah Edu Research. 2013; 2(1): 1526.

4. Karyana, Yayat. Hajarisman N. Geographic Modeling on The Infant Mortality Rate In West Java. MIMBAR. 2016; 32(1): 194-205. 
5. Saepudin D. Geographically Weighted Poisson Regression (GWPRJ) for Analyzing The Malnutrition [Bachelor thesis]. Department of Statistics Faculty of Mathematics and Natural Science: Bogor Agricultural University; 2012.

6. Fox, John. Applied Regression Analysis and Generalized Linear Models. SAGE Publications Inc.; 2015.

7. Lee J dan Wong DW. Statistical Analysis with ArcView GIS. Canada: John Willey \& Sons, Inc.; 2001.

8. Charlton M. dan Fotheringham AS. Geographically Weighted Regression. White paper, National Centre for Geocomputation National University of Ireland Maynooth; 2009.
9. Anselin L. Spatial Econometrics: Methods and Models. Berlin: Springer-Verlag; 2008.

10. Surabaya. Profil Kesehatan Provinsi Jawa Timur. Jumlah Posyandu menurut Strata, Kecamatan, dan Puskesmas Provinsi Jawa Timur. Surabaya: Dinas Kesehatan Provinsi Jawa Timur; 2018.

11. Surabaya. Statistika Kesehatan. Jumlah Klinik Keluarga Berencana (KKB) dan Pos Pelayanan Keluarga Berencana Desa (PPKBD) di Provinsi Jawa Timur. Surabaya: Badan Pusat Statistika Provinsi Jawa Timur; 2018.

12. Surabaya. Statistika Kesehatan. Jumlah Desa/ Kelurahan yang Memiliki Sarana Kesehatan di Provinsi Jawa Timur. Surabaya: Badan Pusat Statistika Provinsi Jawa Timur; 2018. 